\title{
Framing the use of geo-information in government: a tale of two perspectives
}

\author{
Yola Georgiadou • Gianluca Miscione • Kate Lance • \\ Walter de Vries
}

Received: 11 June 2009 / Accepted: 25 September 2009 /Published online: 25 November 2009

(C) Springer-Verlag 2009

\begin{abstract}
While commercial virtual globes (e.g. Google Earth) and global scientific cyber-infrastructures (e.g. Digital Earth) are revolutionizing the way we use and produce geoinformation, we still lack a rich conceptual understanding of how genuine human actors use geo-information and associated technologies in real work settings. In this paper, we conceptualize the use of geo-information as encompassing people's actual use practices, the values to which people aspire through geo-information use, and the rules that either legally prescribe or just encourage optimal use. Values, practices and rules can be illuminated from two perspectives (or lenses), the market and the polis, resulting in radically different insights on the use of geo-information as a social phenomenon. We argue that with a polis lens we stand a chance to explain how authentic human actors, groups and communities with different values, interests and motivations use geo-information, and how societal benefits materialize or not as a result. Seen from a polis lens, values are not easily measurable standards of goodness, dominant public management ideas can be the source of technical-organizational change in government while policies can be fruitfully examined as persuasive arguments to target audiences. With a polis lens, we are more likely to understand the emergence of new practices, value contests and global rules underpinning commercial virtual globes and scientific cyber-infrastructures.
\end{abstract}

Communicated by: H.A. Babaie

SI: Spatial data infrastructures for the Amazon: a first step towards a Global Forest Information System

Y. Georgiadou $(\bowtie) \cdot$ G. Miscione $\cdot$ K. Lance $\cdot$ W. de Vries International Institute for Geo-Information Science and Earth Observation (ITC),

Hengelosestraat 99, PO Box 6, 7500 AA Enschede,

The Netherlands

e-mail: georgiadou@itc.nl
Keywords Geo-information · Use · Values · Practices · Rules $\cdot$ Market perspective $\cdot$ Polis perspective

\section{Introduction}

The use of geo-information in government is a study area of increasing relevance and even urgency. A case in point is the use of earth observation in environmental policy making. In An Inconvenient Truth, Gore (2006) describes how a single image of the Earth from space, taken in December 1968 by a crew member of the Apollo 8 mission, apparently triggered not only the environmental movement but also an assortment of environmental policies: “... within two years of this picture being taken, the modern environmental movement was born. The Clean Air Act, the Clean Water Act, the Natural Environmental Policy Act, and the first Earth Day all came about within a few years of this picture being seen for the first time" (p. 12).

Yet a literature review by de Leeuw et al. (2009) came to a puzzling conclusion. The proportion of earth observation literature referring to policy rose from around $1 \%$ in the early 1990 s to only just above $2 \%$ in 2007 . Out of 300 peer-reviewed papers (obtained by searching the ISI Web of Science with "remote sensing OR earth observation AND policy"), not a single paper describes and analyses how earth observation actually supports policy-making practices. Instead, these papers only demonstrate or claim the potential of earth observation for environmental policy. We know that earth observation is used in environmental policy. However, if we knew exactly how it is used and embedded in actual policy-making practices, we would have a better understanding of how to scale up these practices.

The study of geo-information use shifts the centre of gravity of GIScience towards human agents and their relationship with geo-information and technology. It forces 
us to make explicit our assumptions about the nature of fundamental concepts: humans, geo-information and technology (Table 1). We can model these concepts from a rationalist-analytic or a political-discursive perspective. We follow political scientist Deborah Stone (2002) and use the terms market and polis for these perspectives. The two terms stand for different perceptions of human agency and society that are central to geo-information use. The market comprises individual rational decision makers that are maximising self-interest. The polis implies a political community that does not necessarily follow a mould of consistent rationality, and is instead motivated by public as well as self-interest (Stone 2002). The polis and geoinformation make a perfect couple. Power is a primary characteristic of both. Power in the polis subordinates a group's interest to other groups' interests, or to the public interest. Power is based, among other things, on the strategic control and interpretation of information (Stone 2002). Geo-information is a formidable mediator not only of spatial knowledge but also of social and political power. Geo-information does not only represent the world-for example, as seen by the state - but also, through its use in society, reinforces the power of the state (Harley 1989, 1990; Wood 1992).

The role of policy maps in the European Spatial Development Perspective (ESDP) process is an excellent example of the power of geo-information. The use of maps to visualise spatial problems and policies was so sensitive in the ESDP process that it was decided not to use any maps at all in the final report. The core-periphery map of Europe - known as the "migraine map" - was one of the omitted maps. Faloudi and Waterhout (2002) give an interesting account of the map's fate-from being an apple of discord to its eventual extinction from the final ESDP report. The map shows the distances between Greece, Ireland, Finland and Spain, the natural barriers in-between, as well as the core of Europe, indicated by an elliptical shape. The map reflected a centre-periphery model of Europe, juxtaposing strong regions in the northwest (within the ellipse) and weak regions in the south. The Southern
Europeans were not amused by this vision of Europe, although it was the Southern Europeans themselves who had initially identified regional disparities as the central issue in European spatial development. However, representing disparities on a map was very controversial. A temporary compromise was to leave out the elliptical shape representing the core of Europe. Finally, even this (toothless) revised version was omitted from the final report, as were all other policy maps.

The remainder of this paper is organized as follows. In "A conceptual framework and examples" section, we develop a conceptual framework for the study of geoinformation use and elucidate it by means of examples. In "From a market to a polis perspective" section, we supply arguments for a shift of emphasis in the study of geoinformation use. In "Reflection" section, we reflect on the implications of researching globally dispersed phenomena of use and co-production of geo-information. Conclusions are presented in the fifth section.

\section{A conceptual framework and examples}

We propose a people-centred conceptual framework for the study of geo-information use that encompasses three aspects: the values to which people aspire, people's actual use practices, and the rules that either legally prescribe or just encourage people to use geo-information optimally.

Values Optimal geo-information use is poised to advance certain values, things that people hold dear: e.g. efficiency, equity, legitimacy, privacy, security and sustainability, among others.

Practices People use geo-information in routine, everyday practices: politicians use geo-information in decision and policy making; citizens use it in routine locational questions and civil society groups in participatory planning processes. Bureaucrats use geo-information within a single adminis-

Table 1 Models for fundamental concepts in geo-information use

\begin{tabular}{lll}
\hline $\begin{array}{l}\text { Fundamental } \\
\text { concepts }\end{array}$ & Market or rationalist-analytic model & Polis or political-discursive model \\
\hline Humans & $\begin{array}{c}\text { Autonomous, rational, individual } \\
\text { actors maximising self-interest }\end{array}$ & $\begin{array}{c}\text { Individuals, groups and communities do not follow a mould of consistent } \\
\text { rationality; they display diverse values and interests and are motivated by } \\
\text { public as well as self-interest }\end{array}$ \\
$\begin{array}{l}\text { Geo-information } \\
\begin{array}{c}\text { Geo-information } \\
\text { technology }\end{array}\end{array}$ & $\begin{array}{c}\text { Value-neutral; drives organisational } \\
\text { mediates spatial knowledge } \\
\text { \& social change }\end{array}$ & $\begin{array}{c}\text { Social and political power and is strategically manipulated in policy processes } \\
\text { Valuent historically contingent; shapes and is shaped by social processes }\end{array}$ \\
\hline
\end{tabular}


trative agency, while various governance actors coordinate the sharing of geo information - formally and informallyacross administrative, political, cultural, sectoral contexts, spread out in time and space.

Rules Optimal geo-information use is prescribed in influential texts-policies, principles and declarations of global associations, that attempt to change people's behaviour. Examples are national policies (e.g. free or for-a-fee access policies), national and supranational principles (e.g. promoted by INSPIRE) and declarations promoted by global, professional and academic associations in the field of GIScience (e.g. GSDI, FIG, GEOSS, etc).

The three aspects are neither exhaustive nor mutually exclusive. Nevertheless, they represent a useful and novel heuristic to describe and analyze geo-information use as a social phenomenon, by placing people (and their values, practices and rules) at the centre of the stage. In the following sub-sections we show how the market and polis lenses illuminate values, practices and rules in distinct ways by means of examples.

\section{Values}

The first example concerns values. Values are standards we aspire to through optimal geo-information use. Through a market lens, values offer simple, easily measurable standards that determine goodness. In the polis, values contain ambiguities and problems of interpretation that make them the object of political struggles. Values are continuously socially constructed and are in competition with each other (value trade-offs). We shall examine two values: efficiency and equity.

\section{Efficiency}

No other value has been as pervasive in GIScience as efficiency. Efficiency can be simply defined as "getting the most output for a given input" or "attaining an output for the lowest input". It is the ratio between input and output, efforts and results, expenditure and income, cost and benefit.

A market perspective on the efficiency of geospatial operations and investments focuses on scoring what can be easily measured, or even measured at all. Geospatial managers in the public sector usually take this simple market perspective on efficiency (Lance et al. 2006). They emphasise operations and investment decisions as inputs and typically measure outputs as ratios, percentages and indices of readily and automatically measurable entities. Table 2 shows a typical example: the objectives and efficiency measures of a geospatial clearinghouse serving a metropolitan area in the USA.
Table 2 A market perspective of efficiency for a geospatial clearinghouse

\begin{tabular}{lc}
\hline Objectives & Efficiency measures (outputs) \\
\hline Facilitate widespread & Number of visits/sessions to \\
sharing of geospatial data & DataFinder website \\
by means of improved & Number of entities visiting \\
participant operations, reduced & DataFinder \\
costs, and supporting cross- & Number of whole or partial \\
jurisdictional decision making & datasets and regional datasets \\
& downloaded through \\
& DataFinder \\
& Number of entities listing \\
& metadata on DataFinder \\
& Hours of data-producer \\
& staff time saved \\
\hline
\end{tabular}

Efficiency from a polis perspective poses questions such as the following (Stone 2002, p. 67):

1. Who determines what is the correct output [...]?

2. How should we value and compare multiple [outputs]?

3. How do different [...] outputs benefit different constituencies or groups?

4. How should we count inputs (e.g. labor costs) that are simultaneously outputs to somebody else (e.g. jobs for local community)?

5. How should we decide which of the many benefits of any input to count in the equation?

6. How should we count the virtually unlimited opportunity costs of resources used as inputs?

Efficiency is not a value-neutral technical term but a contestable political claim. Everybody supports the abstract idea of efficiency but to go "beyond the value slogans and apply the concept to a concrete policy choice requires making assumptions about who and what counts as important. There are no correct answers to these questions to be found outside the political process" (p. 65).

Let us consider the "efficiency ratio" of Chicago's geospatial clearinghouse (Elwood 2008). In the city of Chicago, grassroots NGOs provide homeownership counselling or disaster response services to residents in poor neighbourhoods. These NGOs identify and represent the needs of neighbourhood residents. They use their own priorities, semantics and attribute schemes in the geo-information they produce. City officials admit that grassroots NGOs are valuable because they are "always in and out of streets and alleys, and so they're able to tell you the most current information" (p. 83). How can these NGOs - who want to use data and maps from the city's clearinghouse - be included in the efficiency ratio of the clearinghouse cooperative? 
To benefit these NGOs, the clearinghouse cooperative would have to modify, supplement or transform data relevant for the NGOs for the GIS applications, thereby increasing the inputs in the efficiency ratio. It would have to include different browsing, query and selection interfaces. It would have to include the possibility for grassroots NGOs to add non-expert, vernacular descriptions of spatial data, thus increasing both the inputs and outputs of the efficiency ratio. However, the trade-off for the decreased efficiency of the Chicago clearinghouse could be an increase in the legitimacy of the Chicago city administration. Is not legitimacy the ultimate test of successful innovation in public governance (Bekkers 2007)?

\section{Equity}

Equity is the primary goal in the distribution of wealth, goods and services and of information resources. In any distribution, there are three dimensions: the recipients, the item and the process (Stone 2002). Everybody supports the abstract idea of equity, but to distribute equitably poses a number of questions: who should count as a member of the class of recipients? how should the boundaries of the item be (re)defined? how should the item be customised to individual needs? which process of distribution guarantees fairness (Stone 2002)?

Participatory GIS (PGIS) embodies the value of equity. That is why we discuss it under "values" and not under "practices." PGIS is unambiguously situated in the polis. It has no counterpart in the market. PGIS is a genuinely political response to concerns for equity in the distribution of the valuable resource geo-information, related technologies and the societal processes that shape them. PGIS redefines the recipients and the item to be distributed and establishes a process of distribution (Table 3).

The process dimension is integral to the distribution of public goods (and bads). Public goods (e.g. location of city parks) or public bads (e.g. location of city garbage dumps) cannot be distributed in equal slices (equal slices of the park or dump distributed evenly) to all recipients (Stone 2002). Solutions to commons problems are often based on unequal slices of the good or bad but on a fair process (in the case of PGIS a participatory distribution process of geo-information and related technologies). Equity is continuously socially constructed in PGIS. There is never a final solution.

\section{Practices}

The second example concerns two practices: coordination of data sharing and policy making.

\section{Coordination of data sharing}

Sharing data is vital because the more data are shared, the more they are used. Successful sharing of geospatial data occurs in various circumstances. Table 4 summarises successful sharing practices in Australia and the Netherlands (Masser et al. 2007). Through a market lens, data sharing increases when networked, equal, self-organising, rational government actors engage in appropriate technical redesigns, which then drive successful changes in organisational structures.

Through a polis lens, the success or failure of technicalorganisational redesign (seen as a technical-organisational reform) can be explained by foregrounding social factors, for example, dominant public management ideas at the time of the reform. In the polis, dominant public management ideas frame opportunities for reform and shape what and how things should be done and who should do them. We draw on public administration literature, in particular Hood and Jackson (1991) and Hood (1998), to sketch out how a polis lens can be made operational to explain these three successful reforms.

In a particular country at any time, a certain public management paradigm (individualism, egalitarianism, hierarchism or a hybrid thereof) dominates the public sector until that paradigm is deemed inadequate and is replaced by

Table 3 Equity and participatory GIS

\begin{tabular}{|c|c|c|}
\hline $\begin{array}{l}\text { Dimensions } \\
\text { of equity }\end{array}$ & Equitable distribution & Participatory GIS \\
\hline Recipients & $\begin{array}{l}\text { Who should count as a member } \\
\text { of the class of recipients? }\end{array}$ & $\begin{array}{l}\text { Redefines recipients by including resource-poor organisations and "non-traditional" users, } \\
\text { NGOs, grassroots groups, and community-based organisations (McCall 2003) }\end{array}$ \\
\hline \multirow[t]{2}{*}{ Item } & $\begin{array}{l}\text { How should the boundaries of } \\
\text { the item be (re)defined? }\end{array}$ & $\begin{array}{l}\text { Expands the item to also include multimedia strategies (digital photographs, sound files, } \\
\text { sketch maps, etc.) and representations of diverse and vernacular forms of spatial } \\
\text { knowledge in a GIS (Elwood 2006) }\end{array}$ \\
\hline & $\begin{array}{l}\text { How could the item be customised } \\
\text { to individual needs? }\end{array}$ & $\begin{array}{l}\text { "Rewires" the item (as in GIS/2) to represent different visions of place, to support cultura } \\
\text { and multilingual distinctions, to integrate local knowledge (Sieber 2004) }\end{array}$ \\
\hline Process & Which process guarantees fairness? & Participation as distribution process \\
\hline
\end{tabular}


Table 4 Technical and organisational redesign for coordinating data sharing (Masser et al. 2007)

\begin{tabular}{llc}
\hline Cases & Technical redesign & Organisational redesign \\
\hline $\begin{array}{l}\text { SLIP: Shared Land Information Platform, } \\
\text { Western Australia }\end{array}$ & $\begin{array}{c}\text { Creation and maintenance of an integrated } \\
\text { land-information database }\end{array}$ & $\begin{array}{c}\text { Restructuring within government } \\
\text { structures }\end{array}$ \\
$\begin{array}{l}\text { PSMA: Public Sector Mapping Agencies } \\
\text { consortium, Australia }\end{array}$ & $\begin{array}{c}\text { Integration of datasets held by state and } \\
\text { commonwealth agencies }\end{array}$ & $\begin{array}{c}\text { Joint venture: consortium of data } \\
\text { producers }\end{array}$ \\
$G B K N$ : Large Scale Base Map, the Netherlands & Maintenance and dissemination of core datasets & Joint venture by key data users \\
\hline
\end{tabular}

another. Each paradigm is a constellation of doctrines specifying who should do what, and how, in government. Reformers argue for paradigm change using three generic types of justification. Individualist justifications commonly include the limitation of waste, the pursuit of efficiency, and the avoidance of muddle and confusion. Egalitarian justifications include fairness, mutuality, the pursuit of accountability, and the avoidance of abuse of office. Hierarchist justifications include reliability, robustness and resilience, particularly in adverse conditions.

The three technical-organisational reforms (SLIP, PSMA and GBKN) correspond to three sourcing doctrines for government that are well established in the literature (Hood and Jackson 1991; Hood 1998). Reformers defend the change in sourcing doctrine with a battery of also wellknown justifications (Table 5).

SLIP corresponds to a sourcing doctrine known as "single source supply". The doctrine holds that good public administration should avoid rivalry and overlap of producer units for a particular government service. Reformers usually defend it with individualist justifications: effectiveness, avoidance of confusion and deadlocks. PSMA corresponds to a sourcing doctrine known as "multisource supply by the public sector". The doctrine holds that competition and rivalry should be preferred in public administration, andas often happens with doctrines - is exactly the opposite of the previous one. Reformers usually defend it with mixed egalitarian (reduction of the arrogance of office) and individualist (setting up pressures to minimise cost) justifications. GBKN corresponds to a sourcing doctrine known as "multisource supply by metaphytic competition". The doctrine reflects an attempt to engineer competition between the public and private sectors. Reformers usually defend it with mixed egalitarian (keep the private sector honest) and individualist (make the public sector competitive) justifications.

A polis analysis of the three successful instances of data sharing could test the hypothesis that the justifications given by the reformers in Australia (at the provincial and federal levels) and the Netherlands resonated with the dominant public management paradigm in each case and at the time of the reform, with a successful reform as a result.

\section{Spatial policy making}

The power of geo-information is most obvious in spatial policy making, where different group interests collide over different interpretations of geo-information.

If we take a market perspective on spatial policy making, we assume an unproblematic, linear and direct relationship between high-quality geo-information and policy. Geoinformation is an objective and scientifically accurate

Table 5 Sourcing doctrines and justifications related to data sharing practices

\begin{tabular}{|c|c|c|c|}
\hline Cases & Technical-organisational reform & Sourcing doctrine & Typical justifications \\
\hline $\begin{array}{l}\text { SLIP: Shared Land } \\
\text { Information Platform, } \\
\text { Western Australia }\end{array}$ & $\begin{array}{l}\text { Restructuring within government } \\
\text { structures } \\
\text { Creation and maintenance of } \\
\text { an integrated land information } \\
\text { database }\end{array}$ & Single source supply & $\begin{array}{l}\text { Individualist (effectiveness, avoidance } \\
\text { of confusion and deadlocks) }\end{array}$ \\
\hline $\begin{array}{l}\text { PSMA: Public Sector Mapping } \\
\text { Agencies consortium, Australia }\end{array}$ & $\begin{array}{l}\text { Joint venture: consortium of } \\
\text { data producers } \\
\text { Integration of datasets held } \\
\text { by state and commonwealth } \\
\text { agencies }\end{array}$ & $\begin{array}{l}\text { Multisource supply } \\
\text { by the public sector }\end{array}$ & $\begin{array}{l}\text { Mixed egalitarian (serves to reduce the } \\
\text { arrogance of office) and individualist } \\
\text { (sets up pressures to minimise costs) }\end{array}$ \\
\hline $\begin{array}{l}G B K N \text { : Large Scale Base } \\
\text { Map, the Netherlands }\end{array}$ & $\begin{array}{l}\text { Joint venture by key data users } \\
\text { Maintenance and dissemination } \\
\text { of core datasets }\end{array}$ & $\begin{array}{l}\text { Multisource supply } \\
\text { by metaphytic competition }\end{array}$ & $\begin{array}{l}\text { Mixed egalitarian (keeps the private } \\
\text { sector honest) and individualist (keeps } \\
\text { the public sector competitive) }\end{array}$ \\
\hline
\end{tabular}


resource with the role of providing spatially relevant information to rational decision making (Dühr 2007). Either research leads policy and hence policy is evidence-driven, or research follows policy and hence research is policydriven. Of course, we recognise practical problems. For example, spatial policy requires geo-information that is not available - at least not in a timeframe necessary to ensure its relevance to the resolution of the issues of the day. Policy problems require a particular kind of evidence that typically is not immediately to hand. The policy-making process and the information generation process have different dynamics.

In the polis, metaphoric reasoning is essential in spatial policy making. When the ESDP process started, the dominant view was shaped by the policy notion of the "Blue Banana", a rather one-dimensional view of Europe. European regions within the Blue Banana were seen as the economic motor of Europe. The European Commission DG XVI responded with the "European Bunch of Grapes"- a view more suited to the polycentric structure of the urban system in Europe (Faloudi and Waterhout 2002).

In the polis, political arguments are more salient than scientific arguments in choosing between spatial policy options. "The question is not whether planning will reflect politics, but whose politics it will reflect. What values and whose values will planners seek to implement?" (Dühr 2007, p. 21). Carton's (2007) research illustrates how policy actors clash over interpretations of geo-information and how they deal with these controversies. In an empirical study of the role of geo-information in deliberative spatial policy-making practices in the Netherlands, she found that the use of map sketches, geodatabases, GIS analyses, spatial designs or local knowledge often deepened the conflict between policy actors. Policy makers' strategies for dealing with controversies varied from placing the problem in a wider context by extending the region represented on the planning maps, to manipulating the map picture by, for instance, hiding controversial boundaries or adding lightning-rods to the maps to shift the attention of stakeholders towards other issues.

\section{Rules}

The third example concerns policies, principles and declarations. Through a market lens, rational geo-information policies based on hard factual evidence of benefits can be enacted in consultation with fully informed governance actors. Principles and global declarations are invariant as they diffuse from a diffusion centre to adopters. In the polis, policy ideas win over competing ideas by persuasion rather than by hard factual evidence. Adopters "edit" principles and declarations and often reinvent them. Social actors fit ideas to their idiosyncratic needs in a particular location at a particular time.
Policies

Rights of access to public records are still the paramount social issue in optimising geo-information use (Groot and McLaughlin 2000). Two competing positions mark the polar extremes of the debate: direct charging for data on the premise that if you need something you should pay for it, or making data available free to anyone in an "information commons" on the premise that charging would be the equivalent of submitting citizens to double taxation. The debate goes on. Discussions are intense and occasionally heated. In the literature, two distinctive styles of reasoning for or against have emerged. They correspond to a polis and a market perspective.

The market perspective sees policies as blueprints transportable by virtue of factual evidence of benefits and of rational analysis. Burkert and Weiss (2004) compare the open access policies of the US federal government with the restrictive policies of European countries, find the latter inferior, and conclude that open access policies should be implemented in Europe because of significant macroeconomic benefits. They provide a blueprint for best practices to public sector institutions in Europe. Longhorn and Blakemore (2008) argue that rational charging policies can be enacted in consultation with fully informed end users, private citizens, commercial enterprises or government agencies.

In the polis, policy ideas win over competing ideas by persuasion. Competing groups frequently frame their selfinterest as public interest (Litman 1994): "Thus, we have seen an avalanche of proposals to privatize, nationalize, commercialize, or liberate information in general and computerized data in particular. So far, the debate has seemed to be fuelled by some combination of almost religious faith [...] with self interest: those who have invested in data collection argue that the public interest is best served by the enforcement of strong property rights in collected data, while those with an interest in mounting competing products incorporating the data assert that the public interest lies in unfettered movement of information."

For Litman, the way forward is to identify, first, our prejudices about information law and, second, our notions of what the government is, what the government does and what it is for. Onsrud (1992a, b) also underlines the politics of policies. However, in contrast to Litman, Onsrud foregrounds the citizen as "citoyen" and vigilant member of the polis, who should: "Continually question and investigate whether specific approaches provide greater or lesser economic and social equity benefits than others. In democracies, irrational governmental policies are inevitably exposed over time with the result that the system corrects itself. Whether the policies actually implemented by elected officials and government bureaucrats are 
successful or unsuccessful is a determination which again is ultimately made at the ballot box."

\section{(Diffusion of) principles and declarations}

From a market perspective, supranational principles (e.g. INSPIRE) and declarations (e.g. of the GSDI association) are presumed to diffuse from country to country, or from continent to continent, in such a way as though there were some general convergence towards uniform practices and impacts. Ubiquitous political and institutional barriers towards adoption are presumed to exist, while unambiguous sustained capacity building is needed to remove these barriers.

In the polis, principles and declarations are powerful doctrines that integrate behaviour in a sensible way. They are a source of inspiration that experts, politicians and other participants in SDI development can use to enact social reality. Adopters "edit" doctrines and ideas and often reinvent them. Social actors fit ideas to their idiosyncratic needs in a particular location at a particular time. For example, the idea of SDI was developed, transformed and translated in the United States context in which it was conceived. The idea travelled to an African context, and has been translated in that particular context over time. The SDI doctrine in the United States is aligned with theory development and theory use in a clamour for best practices and demonstrated uses of SDI. In Africa, SDI is interwoven with the political agenda of the African Information Society Initiative (AISI) and the National Information and Communication Infrastructure (NICI) community. In neither of the two cases does the rhetoric of SDI team up with the engineering challenge of actually implementing a national SDI (Georgiadou and Homburg 2008).
Summary

Table 6

\section{From a market to a polis perspective}

The examples in " A conceptual framework and examples" section show that the polis models geo-information use more accurately than the market does. The design-reality gap is smaller. Thus, we stand a better chance of understanding and explaining how authentic human actors and groups with different loyalties, ideologies and interests use geo-information. Below we argue that a polis lens would not only counterbalance our current over-reliance on a market perspective of geo-information use but would also allow us to explore new phenomena of geo-information use and co-production.

\section{Over-reliance on a market lens in SDI research}

The prevalence of market concepts in SDI research to date can be explained in three ways:

Lock-in in the new public management paradigm of the early nineties: The inception in 1991 of the SDI concept by John McLaughlin, and further development by Dick Groot and other pioneers, was locked into new public management (NPM), the public management paradigm of the early nineties. Consistent with NPM doctrines (privatisation, performance measurement and public service improvement), SDI initiatives were phrased in terms of economic considerations in those

Table 6 Geo-information use through a market and a polis lens

\begin{tabular}{|c|c|c|}
\hline Geo-information use & Market & Polis \\
\hline Values & $\begin{array}{l}\text { Values offer simple, measurable } \\
\text { rules that determine goodness }\end{array}$ & $\begin{array}{l}\text { Values contain problems of interpretation, thus } \\
\text { becoming the object of political struggles; } \\
\text { continuously socially constructed }\end{array}$ \\
\hline \multicolumn{3}{|l|}{ Practices } \\
\hline Spatial policy making & $\begin{array}{l}\text { Linear relationship between } \\
\text { high-quality geo-information and } \\
\text { spatial policy }\end{array}$ & $\begin{array}{l}\text { Political reasoning (by metaphor and analogy) more } \\
\text { salient than scientific facts }\end{array}$ \\
\hline $\begin{array}{l}\text { Coordinating sharing } \\
\text { of geo-information }\end{array}$ & $\begin{array}{l}\text { Rational actors engage in } \\
\text { technical redesign which drives } \\
\text { organisational change and affects } \\
\text { data sharing }\end{array}$ & $\begin{array}{l}\text { Organisational-technical reforms required for } \\
\text { coordinating geo-information sharing shape and are } \\
\text { shaped by social factors }\end{array}$ \\
\hline \multicolumn{3}{|l|}{ Rules } \\
\hline $\begin{array}{l}\text { Geo-information } \\
\text { policies }\end{array}$ & $\begin{array}{l}\text { Rational policies are enacted in } \\
\text { consultation with fully-informed } \\
\text { governance actors }\end{array}$ & $\begin{array}{l}\text { Policy ideas win over competing ideas by persuasion } \\
\text { rather than by hard factual evidence }\end{array}$ \\
\hline $\begin{array}{l}\text { (Diffusion of ) } \\
\text { principles and } \\
\text { declarations }\end{array}$ & $\begin{array}{l}\text { Principles and global } \\
\text { declarations are invariant as they } \\
\text { diffuse from a centre of diffusion to adopters worldwide }\end{array}$ & $\begin{array}{l}\text { Adopters "edit" principles and global declarations; } \\
\text { they reinvent them to fit their idiosyncratic needs } \\
\text { locally }\end{array}$ \\
\hline
\end{tabular}


early days. The emphasis was on predictability, rationality and efficiency, a key role for central government in SDI building, and harmonious collaboration between rational, autonomous, government actors.

Disciplinary path dependence: The majority of SDI researchers have engineering backgrounds. Given specific objectives and conditions of operations, they design geo-information technology models, techniques or devices. They generate situated explanations, develop explicit inventions and propose practical solutions for problems that are contextually, materially and temporally bounded (Orlikowski and Barley 2001). Their key test is pragmatic. Their aim is to find out what works in specific circumstances and given specific design requirements, but not to explain how and why it works. Furthermore, to account for changing sharing practices, SDI researchers mostly draw from the discipline of business administration. Business administration privileges concepts promoting harmony between information technology investments and the strategic objectives of firms. This state of harmony, referred to as "strategic alignment", requires planned and purposeful management processes to align the strategic context of a firm (and, by extension, of government organisations) with information technology. Lessons from the history of technology: Historians of technology teach us that technology-driven debates, such as those concerning information infrastructures, initially (and understandably) privilege a technical, rational-analytic perspective in knowledge development. Problems in this initial phase are defined in technical terms, needing technical solutions. In later stages of the knowledge development cycle, non-technological dimensions (such as who should pay for the information infrastructure, who owns it and how it should be operated) enter the picture. In an even later stage, social scientists, natural scientists and engineers form multidisciplinary teams to develop and test theories, reflecting on the intricacies of the topic at hand from multiple perspectives. Each and every stage of knowledge development is essential and centrally informs the debate, until a new set of issues comes to the fore, with different arguments, audience, principal authors, concepts and methods.

Authoritative geo-information and voluntarism

In the commercial sector and in social networking, new technologies and online services are dramatically changing the way we use, produce and share geo-information globally. The boundaries between geo-information use and voluntary co-production, between geo-information users and volunteer co-producers, are becoming increasingly blurred. Geo-information use is becoming a slippery concept, maybe even an anachronism.

Already commercial firms such as TeleAtlas, Navteq and TomTom each use web-based customer input to locate and qualify mapping errors and feature updates required in their road network databases. Social networking and collaborative web-based efforts such as Open Street Map, Tagzania, Wayfaring.com, the People's Map, and Platial: The People's Atlas now enable experts and amateur enthusiasts alike to create and share limited, theme-oriented geo-information. Commercially, Google now provides GPS kits to citizens in India to help populate and update road centrelines and attribute data of Google Maps in India.

The potential exists for government to improve the currency of authoritative mapping at national and lower levels by leveraging geo-information voluntarism, particularly in resource-poor environments. Voluntarism radically changes the balance between traditional values, practices and rules. Voluntarism is part of broader public governance innovations and underpins the co-production of social services by state and non-state actors (Moore and Hartley 2008). Assume that a national mapping organisation or a city administration chooses to tap the distributed geospatial knowledge and (energy/time) resources of volunteer contributors - individuals or community groups - to produce authoritative data. The national mapping organisation or the city administration is not the locus of change anymore. The organisation's performance is not the focus of evaluation any longer. Voluntarism in the production of authoritative geoinformation is a governance innovation in the sense of Moore and Hartley (2008). Attention shifts from what happens inside a single organisation to what happens in the new social system of geo-information production. As a result, the right to define and judge the value of the geo-information being co-produced is distributed among all co-producers; new rules and standards are required to take into account the values of volunteers - equity, security, community building, privacy - in the evaluation of the performance of the new production system (Moore and Hartley 2008).

\section{Commercial virtual globes}

Voluntarism underpins global scientific cyber infrastructures such as Digital Earth and commercial virtual globes such as Google Earth. Analyses of the potential and implications of virtual globes are just now surfacing in the literature (Harvey 2007; Dodge and Perkins 2007; Zook and Graham 2007; Blamont 2008; Sheppard and Cizek 2008). In Table 7, we organise the reflections of these scholars on the potential and dilemmas posed by commercial virtual globes in terms of new value contests, new emerging practices and the absence of global rules. 
Table 7 Commercial virtual globes: new values, practices and (absence of) rules

\begin{tabular}{|c|c|}
\hline $\begin{array}{l}\text { Geo-information } \\
\text { voluntarism }\end{array}$ & Commercial virtual globes \\
\hline \multirow[t]{4}{*}{ New value contests } & $\begin{array}{l}\text { Trust: Virtual globes fail to inform users when images have been removed or edited at the request of a government. } \\
\text { Trusting commercial companies may lead to public delusion over what is happening in the world. }\end{array}$ \\
\hline & $\begin{array}{l}\text { Commercial values versus public interest: Image currency and resolution in corporate virtual globes reflect perceptions } \\
\text { of market potential not of public interest. }\end{array}$ \\
\hline & $\begin{array}{l}\text { Legitimacy of visualisations: When visualisations of lay people enter the public discourse or decision making, they can } \\
\text { raise difficult value questions: who has a legitimate voice? whose visualisation is right or more legitimate? }\end{array}$ \\
\hline & $\begin{array}{l}\text { Privacy versus surveillance: Live satellite feeds in commercial virtual globes in the near future will have dramatic } \\
\text { consequences for the identification, tracking and sorting of individuals. With close circuit TV (CCTV) the } \\
\text { controlling power of surveillance is in a few hands; with live satellite feeds, massive surveillance is available } \\
\text { to everybody. }\end{array}$ \\
\hline \multirow[t]{4}{*}{ New emerging practices } & $\begin{array}{l}\text { People participate earlier and offer multiple views simultaneously in planning processes, and especially in } \\
\text { environmental issues; there is online feedback and dialogue. }\end{array}$ \\
\hline & $\begin{array}{l}\text { NGOs replace the moralistic rhetoric of "ought" with a technical analysis of "is". NGOs offer technical analyses } \\
\text { countervailing those of intelligence agencies and cause shifts in the epistemic balance of power between civil } \\
\text { society and the state. }\end{array}$ \\
\hline & Activists consciously re-purpose mapping and satellite imagery as resistance to military secrecy. \\
\hline & $\begin{array}{l}\text { Play and aesthetic performance: People derive pleasure from searching for black helicopters, engage in virtual } \\
\text { tourism and creatively make subversive mash-ups. }\end{array}$ \\
\hline Absence of new rules & $\begin{array}{l}\text { No global privacy standards: Google's architecture is based on numerous data centres, each containing hundreds } \\
\text { of servers, with each server operating under different (or no) rules in different countries. }\end{array}$ \\
\hline
\end{tabular}

Surprisingly, it is Google's Global Privacy Counsel, who worries about the lack of global rules, particularly the lack of global privacy standards (Fleischer 2007). Fleischer argues that the most globalised and transportable commodity in the world today, data, should be given treatment similar to aircraft safety or influenza pandemics. We concur with Blamont's conclusion that the most troubling effect is that we don't grasp the consequences of the use of space products by millions of users (Blamont 2008).

Let us have a look at the unanticipated effects of Satnav products used by millions of users, as reported in the New York Times, 4 December 2007. The little village in Fig. 1 is

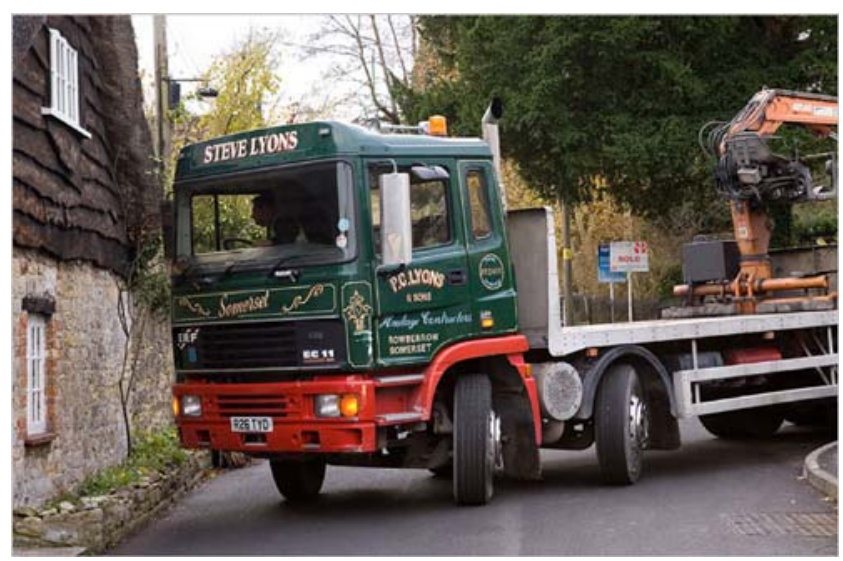

Fig. 1 Satnav products hit the mass market. http://www.nytimes.com/ 2007/12/04/world/europe/04gps.html not an obvious place through which to drive "your average large truck. It is in an obscure, rural location. Its streets were built in the days of horses and carts. There is no room to pass and no room to manoeuvre. But trucks and tractortrailers come here all the time, as they do in similarly inappropriate spots across Britain, directed by G.P.S. navigation devices that fail to appreciate that the shortest route is not always the best route. 'They have no idea where they are, 'said [...] a local store owner who watches a daily parade of vehicles come to grief-hitting fences, shearing mirrors from cars and becoming stuck at the bottom of [the] hill. Once, he saw an enormous tractor-trailer speeding by, unaware that in its wake it was dragging a passenger car, complete with distraught passenger."

We had not anticipated the effects of Satnav products in the mass market. Can we anticipate the consequences of real-time high-resolution satellite feeds in commercial virtual globes, a prospect that is even now technically feasible?

\section{Reflection}

In the introduction, we contrasted Al Gore's statement of the power of a single picture of the Earth from space with the scarcity of research on the actual use of earth observation in policy making. We return to the same theme in this reflection. In October 2004, the global air pollution map produced by ESA's Envisat became available. This map of nitrogen dioxide $\left(\mathrm{NO}_{2}\right)$ pollution depicts air quality 
worldwide. Dutch politicians were shocked to see their country portrayed as the unhealthiest in Europe on the front page of the newspapers. In November 2008, Dr Jan de Leeuw emailed a senior scientist from the Netherlands Environmental Assessment Agency and asked what the impact of the $\mathrm{NO}_{2}$ map had been on environmental policy making in the Netherlands:

"I know that the publication of NO2 maps in 2005 provoked a strong public reaction because they showed that concentration levels of NO2 above the Netherlands were too high [...] Is it known to you whether the information has led to policy change in the Netherlands with respect to NO2 emissions?" (de Leeuw, November, 2008).

The senior scientist of the Netherlands Environmental Assessment Agency answered:

"Such a question is naturally not easy to answer objectively [...] I do not think that the NO2 map has had direct influence on policy rules and goals [...]. Also air quality policy goals have not been sharpened [...] It is possible that the map has contributed to more willingness to accept measures but, I cannot substantiate this claim" (senior scientist, November, 2008, our emphasis in bold).

We need to substantiate, understand and explain the use and scaling up of geo-information in the real world of practice: in the coordination of data sharing, in decision making, in policy making, in peer production environmentsscientific and commercial, national and global. Currently, we study SDI evolution and decision-making practices as well as coordination and sharing practices at a local level. Our empirical focus is city and national government (left in the dark grey area in Fig. 2). We draw on research methods and concepts that are well established in public administration and information systems research. Public administration, a core reference discipline for geo-information use in governance, is rooted in political science, sociology, economics and law. Information systems, a hybrid field merging informatics with social theory, studies information systems implementation and evolution (Avgerou and Madon 2002). Working at the intersection of GIScience, public administration and information systems may offer new insights into geo-information and public governance innovation to all three research communities.

In the future, we need to engage in the study of geoinformation use in policy making, as well as in the study of new global phenomena: voluntarism and authoritative data production, large-scale SDI evolution, and global participation in scientific cyber infrastructures and commercial

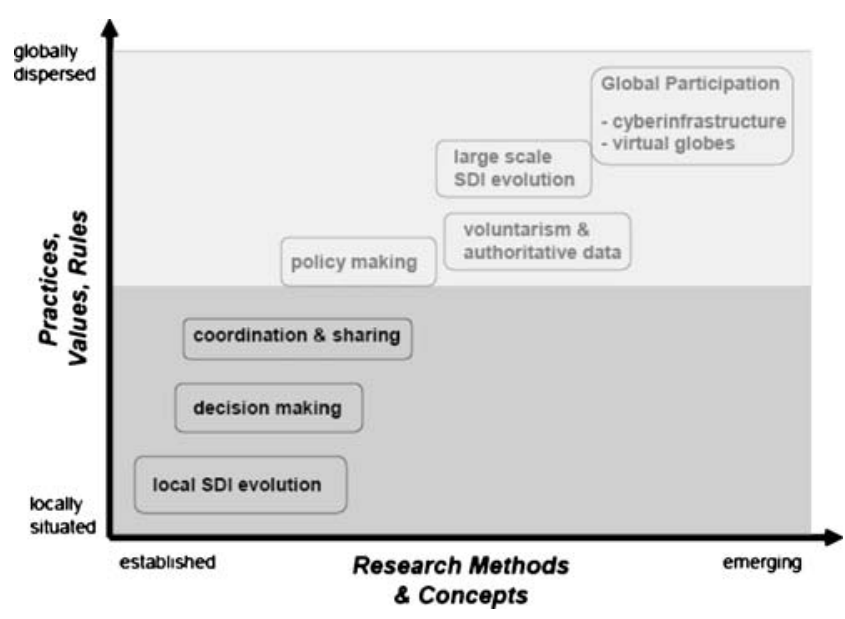

Fig. 2 Geo-information use - from local to global; from established to emerging, methods and concepts

virtual globes (right in the light grey area in Fig. 2). As we move from locally situated to globally dispersed phenomena, established research methods and concepts will be less and less useful. In the future, we need new research methods and concepts that can shape and guide our thinking about global infrastructural development in science (cyber infrastructures) and commerce (virtual globes). Emerging methods and concepts are discussed in scientific fora led by the Office of Cyberinfrastructure of the National Science Foundation of USA (Edwards et al. 2007). They are debated in the International Federation for Information Processing (IFIP) Technical Commission 9, dedicated to issues concerning computers and society.

There seem to be two research approaches to study values, practices and rules related to geo-information in globally dispersed settings: one involves confronting the design of geo-information systems \& infrastructures with what happens when they touch the ground of actual implementation and use; the second relates to whether and how geo-information systems \& infrastructures become part, or not, of policy cycles and administrative practices.

Lacking initial hypotheses for the study of the use of geo-information, we need to resort to inductive and exploratory qualitative research. However, globally dispersed socio-technical patterns present a paradox for the qualitative researcher. Qualitative studies often claim the need for holistic understandings to counterbalance the sliced, narrow representations produced by quantitative methods. An empirical root of such stance is in participant observation. The problem though is that the unity of experience related to a specific place cannot be taken for granted in case of globally dispersed artifacts like SDIs. Mutual alignment between a specific setting, local behaviors and the researcher is challenged by phenomena comprising a plethora of actions happening in 
different places and times simultaneously. How to expand our view without loosing holistic sensitivity?

Engeström (2006) argues that well-bounded ethnography misses the always unfolding aspects of human activity, and pleads for unbounded ethnography. Star (2002) writes that we can only see the faucets of infrastructures; they are so taken-for-granted in our daily life, that we note them mainly when there is a breakdown. Star and Ruhleder (1996) invite us to conceptualize infrastructures as something that is more "when," and less "what" and to emphasize how actors getting "plugged in" over time. These authors provide bases to look at geo-information use at a global scale without missing the continuous unfolding. We need to scale up our methods to grasp better the elusive empirical nature of geo-information use, which always seems to 'happen' somewhere else.

\section{Conclusions}

We distinguished two contrasting perspectives (or lenses) that shape researchers' engagement with humans, geoinformation and technology. We developed a peoplecentered conceptual framework that disaggregates the phenomenon of geo-information use into manageable aspects-values, practices and rules. We illuminated these aspects from a market and polis lens, and showed how radically different insights can be obtained in each case.

We discussed why researchers have relied in the past mostly on market concepts to describe the use of geoinformation in government. We argued we should enrich the debate from other perspectives: voluntary contributions to authoritative government geo-information can radically shift the traditional balance of practices, values and rules; scientific cyber infrastructures and corporate virtual globes are already introducing new practices and new value contests, and point to the need for global rules. The stakes are high. Even sceptics of the polis lens should welcome every form of prosthesis to tackle these new challenges.

With a polis lens we stand a chance to understand and explain in different ways how authentic human actors, groups and communities with different values, interests and motivations use geo-information and how societal benefits materialize or not as a result. In the future, we need new 'rules of the road'; new research methods and concepts that can shape and guide our thinking about global infrastructural development, in science and in commerce. "Moving between social organisation and technical infrastructure is like crossing the Northwest Passage: seasonal shifts in ice mean that the voyage can be made, but never in the same way twice. Under such conditions, what is needed are not rigid maps, but flexible and creative principles of navigation." (Edwards et al. 2007)

\section{References}

Avgerou C, Madon S (2002) Framing IS studies. Working Paper Series 112, Department of Information Systems, London School of Economics and Political Science

Bekkers V (2007) Modernization, public innovation and information and communication technologies. Inform Polity 12(3):103-107

Blamont J (2008) We the people: consequences of the revolution in the management of space applications. Space Policy 24:13-21

Burkert H, Weiss PN (2004) Towards a blueprint for a policy on public sector information. In: Aichholzer G, Burkert H (eds) Public sector information in the digital age. Edward Elgar, Cheltenham

Carton LJ (2007) Map making and map use in a multi-actor context: spatial visualizations and frame conflict in regional policy making in the Netherlands. JB\&A Grafische Communicatie, Delft

de Leeuw J, Georgiadou Y, Kerle N, de Gier A, Inoue Y, Ferwerda J, Smies M, Narantuya D (2009) The function of remote sensing in support of environmental policy, submitted to Remote Sensing of Environment for peer review

Dodge M, Perkins C (2007) Secret sites and satellite imagery: a possible reversal of the Panopticon? Google Earth as the "view from nowhere": the spatial politics of high resolution satellite imagery II. Annual Meeting Association of American Geographers, San Francisco, California, April 2007

Dühr S (2007) The visual language of spatial planning: exploring cartographic representations for spatial planning in Europe. RTPI Library Series, Routledge

Edwards PN, Jackson SJ, Bowker GC, Knobel CP (2007) Report of workshop history \& theory of infrastructure: lessons for new scientific Cyberinfrastructures. NSF Grant 0630263, Human and Social Dynamics, Computer and Information Science and Engineering, Office of Cyberinfrastructure, January 2007. (http://deep blue.lib.umich.edu/bitstream/2027.42/49353/3/Understanding Infrastructure2007.pdf)

Elwood S (2006) Critical issues in participatory GIS: deconstructions, reconstructions, and new research directions. Trans GIS 10 (5):693-708

Elwood S (2008) Grassroots groups as stakeholders in spatial data infrastructures: challenges and opportunities for local data development and sharing. Int J Geogr Inf Sci 22(1):71-90

Engeström Y (2006) From well-bounded ethnographies to intervening in mycorrhizae activities. Organ Stud 27(12):1783-1793

Faloudi A, Waterhout B (2002) The making of the European spatial development perspective: no masterplan. RTPI Library Series, Routledge

Fleischer P (2007) The need for global privacy standards. UNESCO Conference, Ethics and Human Rights in Information Society, 13-14 September 2007, Strasbourg. (http://portal.unesco.org/ci/en/ files/25452/11909026951Fleischer-Peter.pdf/Fleischer-Peter.pdf)

Georgiadou PY, Homburg V (2008) The argumentative structure of spatial data infrastructure initiatives in America and Africa. In: Avgerou C, Smith ML, van den Besselaar P (eds) Social dimensions of information and communication technology. Springer, Boston, pp 31-44 (International Federation for Information Processing, 282)

Gore A (2006) The Inconvenient Truth: A Global Warning. Rodale, New York 325 pp

Groot R, McLaughlin J (2000) Geospatial Data Infrastructure: Concepts, Cases and Good Practice. Oxford University Press, Oxford $286 \mathrm{pp}$

Harley BJ (1989) Deconstructing the map. Cartographica 26(2):1-20

Harley BJ (1990) Cartography, ethics and social theory. Cartographica 27(2):1-23 
Harvey F (2007) Just another private-public partnership? Possible constraints on scientific information in virtual map browsers. Environ Plann B: Plann Des 34:761-764

Hood C (1998) The art of the state: culture, rhetoric and public management. Oxford University Press, Oxford

Hood C, Jackson M (1991) Administrative argument. Dartmouth, Aldershot

Lance KT, Georgiadou PY, Bregt A (2006) Understanding how and why practitioners evaluate SDI performance. IJSDIR 1:65104

Litman J (1994) Rights in government-generated data. Proceedings of the Conference on Law and Information Policy for Spatial Databases, National Center for Geographic Information and Analysis and the Center for the Study of Law, Science and Technology, Arizona State University College of Law, held October 28-29, 1994, Tempe, Arizona. (http://www.spatial. maine.edu/ onsrud/tempe/tempe94.html)

Longhorn R, Blakemore M (2008) Geographic information: value, pricing, production and consumption. CRC/Taylor \& Francis Group, Boca Raton $230 \mathrm{pp}$

Masser I, Rajabifard A, Williamson I (2007) Spatially enabling governments through SDI implementation. IJGIS 22(1):5-20

McCall M (2003) Seeking good governance in participatory GIS: a review of processes and governance dimensions in applying GIS to participatory spatial planning. Habitat Int 27:549-573
Moore M, Hartley J (2008) Innovations in governance. Public Management Review 10(1):3-20

Onsrud HJ (1992a) In support of open access for publicly held geographic information. GIS Law 1(1):3-6

Onsrud HJ (1992b) In support of cost recovery for publicly held geographic information. GIS Law 1(2):1-7

Orlikowski WJ, Barley SR (2001) Technology and institutions: what can research on information technology and research on organizations learn from each other? MIS Quarterly 25(2):145-165

Sheppard SRJ, Cizek P (2008) The ethics of Google Earth: crossing thresholds from spatial data to landscape visualisation. J Environ Manag. doi:10.1016/j.jenvman.2007.09.012

Sieber R (2004) Rewiring for a GIS/2. Cartographica 39(1):25-39

Star SL (2002) Infrastructure and ethnographic practice. Scand J Inf Syst 14(2):107-122

Star SL, Ruhleder K (1996) Steps toward an ecology of infrastructure: design and access for large information spaces. Inf Syst Res 7 (1):1111-134

Stone D (2002) Policy paradox: the art of political decision making. Norton and Company, New York Revised edition

Wood D (1992) The power of maps. Guilford, 1992; Routledge, 1993, Great Britain, $248 \mathrm{pp}$

Zook MA, Graham M (2007) The creative reconstruction of the Internet: Google and the privatization of cyberspace and DigiPlace. Geoforum 38(6):1322-1343 